\title{
Racist dreams and municipal budgets: women representing a culturally racist party in local politics
}

Diana Mulinari and Anders Neergaard

\author{
Linköping University Post Print
}

\section{Tweet}

N.B.: When citing this work, cite the original article.

This is an electronic version of an article published in:

Diana Mulinari and Anders Neergaard, Racist dreams and municipal budgets: women representing a culturally racist party in local politics, 2015, Social Identities, 1-18.

Social Identities is available online at informaworldTM:

http://dx.doi.org/10.1080/13504630.2015.1081561

Copyright: Taylor \& Francis (Routledge): SSH Titles

http://www.routledge.com/

Postprint available at: Linköping University Electronic Press

http://urn.kb.se/resolve?urn=urn:nbn:se:liu:diva-121417 


\begin{abstract}
The welfare and migration regime of Sweden are undergoing substantial changes, as neoliberal restructuring is rapidly increasing inequalities, and multicultural policies are in retreat as neo-assimilationist policies are growing. In 2014 the Sweden Democrats, a party that we conceptualised as cultural racist, was re-elected with $13 \%$ of the votes, with a presence in almost all municipalities. While scholarship on this and similar parties have expanded, the role gender and gender equality has for the cultural racist articulation of their agenda remains unexplored.

It is the experience of women organised in the Sweden Democrats that is the focus of this article, the experience of these women engaged in local politics, working to include Sweden Democrats cultural racist agenda at the municipality level.

The article draws upon in depths interviews with women activists of the Sweden Democrats. Central to the article is an analysis of forms of inclusion and normalisation of the Sweden Democrats worldviews but also of the forms of resistance towards their presence at the municipality level. Unlike mainstream research which downplay the cultural racism of extreme right-wing parties, and rarely employ a gendered analysis, we see (cultural) racism and anti-feminism as central for their agenda.
\end{abstract}

Keywords

Cultural racism, gender politics, local politics, women activists, Sweden Democrats 


\section{Racist dreams and municipal budgets: women representing a culturally racist party in Swedish local politics}

\section{Introduction}

Within academia interest is increasing in studying the growth and success of extreme rightwing parties in European states and within the European Union, evidenced by a large number of edited volumes and journal articles. While there is no consensus on how to name them, nor on their impact or projected impact in democratic government, there is general agreement that the rise and fluctuations of this broad spectrum of parties say a number of important things about politics in Europe today.

In September 2014, the Sweden Democrats (SD) were re-elected to the Swedish Parliament with $12.9 \%$ of the votes, doubling the support they received in the 2010 general election, and now having a presence in almost all municipalities and counties. Although scholarship on extreme right-wing parties is expanding, gender analysis is often marginalised. It is the experience of women organised in the Sweden Democrats that is the focus of this study, which aims to contribute to an understanding of women representing what scholars conceptualise as extreme right-wing parties in local politics. Central to the article also is an analysis of forms of inclusion and normalisation of the SD's policies, as well as of forms of resistance towards their presence (and worldviews) at the municipality level.

\section{Swedish welfare regime in transition}


Sweden has long been seen as the nonpareil of what Esping-Andersen (1990) called the social-democratic model of welfare state. At the same time, although not without contentious discussions (Lister, 2009), feminist researchers have argued that the Swedish regime has resulted in increasing gender equality (Siim, 1994; Sainsbury, 2004). It should be underlined that women's parliamentary success has taken place in the context of a shift towards neoliberal discourses and policies (Boreus, 1997; Selberg, 2013), which have affected the lives of large sectors of the population.

Less known is the particularity of the ethnic regime that in the 1980s grouped Sweden together with the UK and the Netherlands as prime examples of multicultural regimes in Europe (Castles and Miller, 2003). Compared the UK and the Netherlands, as well as to the other Nordic countries, Sweden has a larger proportion of foreign-born, among the highest in Europe (Vasileva, 2011), 16\% in 2014 (21\% Swedish-born with two foreign-born parents, and $29 \%$ with one foreign-born parent) (SCB, 2015). Thus, besides having been the epitome of a social democratic welfare regime with women-friendly policies, Sweden has also been noted for its multicultural policies, which extended substantial citizenship, welfare and labour rights to migrants (Schierup, Hansen and Castles, 2006). ${ }^{1}$ However, the burgeoning of neoliberal reforms and changes in refugee and migration policies, named 'Swedish exceptionalism', is now quite rapidly eroding; some would even argue that a new, neoliberal model is in the making (Schierup and Ålund, 2011). Sweden is today high on the list of OECD members with respect to rapidly increasing inequality of various kinds, albeit from a low starting point (OECD, 2013) such inequalities exert an especially serious impact on the working class,

\footnotetext{
${ }^{1}$ Two qualifications are needed here. First, as Pred (2000) formulated eloquently with the title 'Even in Sweden', racism and racist violence have been present in Sweden. Second, the reference to migrants and substantial citizenship does not include irregular migrants (Sager, 2011).
} 
particularly on the youth, women and migrants (Andersson and Molina, 2003; Nyberg and Jonsson, 2009).

Despite a general multicultural policy, right-wing parties in particular but at times also the Social Democratic party have argued for linking citizenship with assimilationist policies concerning migrants' identification with 'Western values' (e.g. suggestions of a citizenship test or a cultural canon) (Hübinette and Lundström 2014). The assimilationist debates among mainstream parties are in many ways focused on Muslims, a development that shows similarities with Denmark, Norway and Finland (Gullestad, 2002; Keskinen, 2013; Berggren and Neergaard, 2015) .

The intersection of neoliberal politics, gender equality reforms and a racial regime focusing on the Muslim Others as a threat, has played out in different political repertoires of racism, which we have earlier distinguished as exploitative and exclusionary racism (Author/s reference a). Their gender agendas are very different. While exploitative racism is based on the inclusion of migrant women and men as cheap labour, particularly in the field of care work, sex and service work, exclusive racism is based on racist representations of violent and dangerous racialized men and migrant women with children-both threatening the nation.

\section{Racism at the core of extreme right-wing parties}

Extreme right-wing parties have been given many names: extreme right (Mudde, 2000), extreme right-wing populism (Rydgren, 2005a), radical right-wing populism (Rydgren, 2005b), populist parties of the right (Betz, 2005), populist radical right parties (Mudde, 2007) 
and fascist (Arnstad, 2013) - reflecting variation over time and place, different theoretical perspectives and different analytical approaches. In this field of research, we use the term extreme right-wing parties (ERPs). ${ }^{2}$ However, in conceptualising the Sweden Democrats in our research, the issue of racism has come to the fore again and again. Although it is difficult to surmise to what extent exclusionary racism is a programme for political mobilisation and to what extent it is a programme for actual political implementation, it highlights the ambiguity in analysing parties named differently. Inspired by Fennema (1997), we see these parties as combining three political positions in a complex, contextual and time-shifting fashion: as protest parties, in which the rhetoric against migrants is an important but not dominant aspect; as racist parties, based on a praxis in which other political elements are subordinated to a logic of racism; and as fascist parties, based on a more profound transformative character.

Even though the strictly biological view of racism is propounded by a small proportion of these parties, a label based on theories about neo-racism (Barker, 1981; Balibar, 1991) or cultural racism (Blaut, 1992; Billig, 1995) reflects their ideological profiles. This form of racism is characterised by two key assumptions: first, that culture (or religion) is a feature that is essentially similar to biology, an essence; second, that there is a 'natural' connection between place (nation) and culture, and often that 'our' culture is claimed to be superior. Inspired by this research tradition in general and by the notion of new racism in particular, we conceptualise the Sweden Democrats as a cultural racist party, emphasising, however, that the SD's historical roots are neo-fascist and located in neo-Nazi movements with a biological racist agenda, and in their interpellation are strongly influenced by populist rhetoric.

\footnotetext{
${ }^{2}$ See Table 7.1 in Berggren and Neergaard 2015, p. 194.
} 
In capturing the cultural racism of the $\mathrm{SD}$, we are inspired by the growing body of feminist scholarship on the role of nationhood, gender and sexuality in ethno/racist nationalism (Bacchetta and Power, 2002; Puar, 2007). Feminist scholars have argued that women play a central role in the symbolic construction of the nation and its boundaries and are central actors in the construction of narratives of exclusionary belonging (Bulbeck, 1997; Kaplan et al., 1999). Feminist-influenced historical scholarship has identified the central role that gender and women played in earlier fascism (Passmore, 2003) and Nazism (Koonz, 1987). They have also explored the role of gender within emergent extreme right-wing parties in Europe (Towns et.al., 2014).

We are particularly inspired by sociologist Patricia Hill Collins's exploration of the connections between the family as a form of gendered social organisation, racial ideas and practices and the construction of US national identity (Hill Collins, 1998). The author identifies the family as a central arena for discourses on heritage, blood and natural (and necessary) hierarchies, which underline notions of nationhood and belonging. A similar argument is developed by political scientist Nira Yuval-Davis (2012), which further develops intersectionality through an analysis of multiple forms of identification and belonging structuring social relations, from kinship and nationhood to religious communities and transnational spaces. The author's focus is on the link between the act of belonging and the creation of specific political projects. The concept of care racism (author/s reference b) may be seen as one way of analysing cultural racism, in which gender notions on women's care role act upon exclusionary imaginaries of nationhood and belonging (Anthias and YuvalDavis, 1992). 


\section{Methodological framework}

Methodological debates are at the core of both feminist (De Vault, 1996) and antiracist (Back, 2007) scholarship, and they become even more central in studying what Esseveld and Eyerman (1992) call 'distasteful social movements'. The collection of the empirical material took place between 2008 and 2014. Almost twenty interviews were conducted with female municipal representatives of the SD, including a few with migrant backgrounds. The informants were selected from the total population of female representatives in municipal (45) and regional (2) councils. We used the official documents from the electoral board and the municipalities to create the population, employing a saturation model in which we stopped when women's narratives allowed us to identify similar patterns regarding shared experiences of family and paid work. The interviews were semi-structured and carried out individually by a research assistant. The informants covered three paths to political participation: a couple of (young) women with earlier experience of neo-Nazi movements, a few women who had been active in established political parties before, and the more prevalent path in which the Sweden Democrats was their first experience of politics. While this article is based mainly on interviews and texts written by the party or its representatives, the project encompassed in addition participant observation of three municipal assemblies engaged in discussing, debating and deciding on the budgets, collection and analysis of the official documents of the party available on the web, as well as on their website, and their party newspaper $S D$-kuriren (earlier available on the web, now closed), and finally web newspaper articles.

\section{A study of the Sweden Democrats}


The Sweden Democrats have changed from being an overtly racist and neo-Nazi organisation (Deland and Westin, 2007) into what we conceptualise as a culturally racist party. Electoral progress brought the SD in less than two decades from extreme marginality, without parliamentary representation, through local success with municipal representation to the national parliament in 2010 , with $5.7 \%$ of the popular vote, and to being the third largest party in 2014 , with almost $13 \%$ of the votes. While the SD today is a national established party with representation in almost all municipalities, very little research has been done aimed at capturing the position of women within the party. The Sweden Democrats have over 9,000 members and increasing (one-fifth being women). In the municipal and country elections, the Sweden Democrats have a comparatively low percentage of women representatives, although the numbers are steadily increasing.

Table 1 in here

Estimates (from exit and opinion polls) put the female vote at around a quarter to a third, which is in line with voting patterns in other European countries. However, when it comes to opinions on migrants and migration, Swedish women generally are more favourably inclined towards both migration and migrants than are men (Mella and Palm, 2013), whereas, according to Mudde (2007), there is little gender difference in most other countries. This contextual background underscores the importance of gender-aware analysis of cultural racist parties (Norocel, 2013).

\section{Women in local politics}


The Sweden Democrats are one of the most top-down organised parties in Sweden

(Wängenerud, 2012), a situation reinforced since their entry into the national parliament. The latest communication directive of the party states:

We work professionally and methodically with our communication and ensure that it complies with the same central thread, sends out the same signals and conveys the same values, across the country. (Sverigedemokraterna, 2012b, p. 4)

This means that not only the national policy programmes exist to guide SD politicians but also centrally written circular municipal proposals for local politicians to submit to the city councils. The tight control exercised by the party leadership also reflects the almost permanent embarrassment caused to them by local SD politicians articulating outright and vulgar racist ideas in the media and on the Internet. To deal with both these aspects, the leadership adopted a zero tolerance policy on racism, which has been used regularly through expulsions, to distance the party (leadership) from outright racist rhetoric and also to maintain a full grip on the party. ${ }^{3}$ Furthermore, the party has had difficulties both in finding willing candidates to stand for election and with elected officials resigning their council positions at a much higher rate than in other parties. ${ }^{4}$

Municipal politics in Sweden is a (relatively) autonomous and important pillar of the political system, thanks to its taxation power. Almost all income tax is decided upon by local and

\footnotetext{
${ }^{3}$ In April 2015, the party board expelled a number of members, among them the chairman and vice chairman of the formally autonomous youth association - SDU - of the party.

${ }^{4}$ One should, however, be careful about drawing firm conclusions on specific aspects of the $\mathrm{SD}$, as this also reflects the situation of any new party whose representatives are poorly schooled and not yet fully aware of what the role of an elected city council representative entails.
} 
regional municipalities, financing among other things education, social and healthcare services. Although much of the general framework of policies and reforms is decided in the national parliament, their implementation, with important varying degrees of discretion, is left for the municipalities. For the Sweden Democrats, the route to the national parliament has been through municipal elections (which do not have the $4 \%$ bar of national elections). The number of city council members of the Sweden Democrats nationally after the last four elections had increased dramatically from 49 in 2002 to 266 in 2006, to 612 seats in 2010 and to 1,324 in 2014 .

In the city councils a number of important decisions can be made; however, there are others that are outside their legislative scope. Many political issues concerning migration, multiculturalism and integration, of particular importance to the Sweden Democrats, are regulated by the national government and parliament (Fjæstad and Björkman, 2012). In this context, the Sweden Democrats have had to develop local policies on a number of questions other than those regarding migration and migrants (Ekström von Essen, 2006).

The 'local' has a strong symbolic importance in SD policies, being understood as 'authentic'. At the same time, many representatives of other political parties to whom we spoke in the early phase of the SD's success were confident that the specific form of Swedish local politics, with its solid tradition of party collaboration and local administration, would force the SD to abandon their radical and racist rhetoric. One political representative of the Left Party, Alejandra, argued:

Give them one year, a week's discussion about the municipal gardens budget, and it will be the end. Believe me, not even Jimmie [referring to the party leader] 
can say something racist about the municipal gardens budget. [Participant's observation notes from listening in the break of a city council meeting]

Thus, it was expected either that municipal politics would force the SD to adapt or they would risk being dissolved. This second hypothesis was indirectly argued by the media with reports on the difficulties that the SD faced in filling their positions within the councils, the criminal or neo-Nazi past of some of the SD representatives and their high level of absence from important council meetings. However, homophobic rhetoric, sexist rhetoric and especially racist rhetoric are regularly exhibited, as when a leader of the SD in the fourth largest city, on his Facebook page, defended the brutal attack against the Pride demonstration by a more radical and violent organisation, calling Pride a 'perverse stunt', and argued that gender equality in Sweden means that women, despite having less job experience, will be ahead of a 'normal Swedish man' in the work queue (Skeri, 2010). Another example is a SD representative, forced to leave his position in the council after publicly writing that 'Negroes are genetically coded to rape women and children' (Arvidsson, 2010). A third is a SD member, a teacher who wrote in her blog, 'I hope they die of starvation', in response to the hunger strike organised by unaccompanied refugee children demanding their right to stay in the country (Baas and Holmén, 2013).

But, despite media coverage regarding these and numerous other events, the hope that the demands of everyday local politics would, together with the constant media exposure of SD representatives as racist, weaken the SD as an organisation or its support has proven completely wrong. 
In understanding this, the informants often argued that what characterises the party is that they 'tell things straight' and speak the truth that no one else dares utter. As Ulla, a party member in her late sixties active in municipality politics, argues:

Actually, what's good about the Sweden Democrats is that they tell you the truth the other parties don't... We're, we try to say things straight, and we take on the problems that other parties want to sweep under the carpet.

In the informants' self-image of the party, there is a deep distrust of politics and the other political parties. The notion of the truth is a central element in her worldview and in the Sweden Democrats' political profile. She does not explore the possibility that other political parties could think differently or disagree with her definition of the problem. The 'truth' (that migration is a problem and a threat to the Swedish welfare state) is, in her narrative, a point of departure, a fact. Other political parties, according to Ulla, also know the real truth, but consciously conceal it. The binary opposition between the courageous Sweden Democrats speaking the truth and the others cowardly suppressing it provides a positive sense of self, both to the party and to the informants we interviewed.

The next argument demonstrates how local politics is experienced and acted upon, as described by another of our informants, Annika, a woman representative of the Sweden Democrats at the municipal level:

There is a lot; well, politics is complicated, so to speak. Let me tell you that every time I arrive at the city council, I know that our proposals will be voted down. So it's perhaps a little bit difficult to try to change how local politicians 
perceive the city. I try, but what can I do if everybody here is proud of the city as a multicultural city? They say that it is just this that makes the city what it is. What would you do in my situation? What should I say? For example, you've got issues such as whether a property should be sold or not. And there, it's not so much ideology in it, and I cannot see that there is a lot of ideology at all in municipal politics. But there, that of course also varies from municipality to municipality.

While there are a number of examples of how established parties have tried to improve their electoral position by interpellations concerning the image of the cities, the presence of the Sweden Democrats adds a new angle. In one of the municipalities in which we did participant observation, it became obvious that, in describing the city, the governing coalition was in conflict with the Sweden Democrats. The governing coalition emphasised the city as an open, interesting and multicultural place, whereas the SD highlighted it as a dangerous, high-crime and "Islamised" city.

Annika's narrative grasps identity formation regarding the sense of pride that the city residents often express, as a response to mainstream national media identification of the city as a Swedish Chicago (Mukhtar-Landgren, 2008). Maybe in response to this characterisation, there is a strong consensus on the positive aspects of the multicultural city among its residents and even among the local media, which is mirrored on the city's web page (Malmö Stad, no date). 'Our parents may come from very different places but we, we are from Malmö' was the catchphrase of one of Malmö's most loved hip-hop artists, whose young audience would echo him, chanting loudly, 'We are from Malmö'. What may be called the Malmö spirit has been 
central in articulating political mobilisation against neo-Nazi violence with slogans such as Malmö against racism, Malmö Nazi-free zone and Malmö in struggle.

It is this city identity that Annika encounters in the municipal council: an identity that she would argue is a faulty and dangerous perception of the city that also excludes from the political agenda the Sweden Democrats' understanding of the city, which portrays it as in decline owing to the catastrophic consequences of (Muslim) migration.

Annika highlights that local politics has no ideological weight, while simultaneously indicating active ideological work that is trying to change the image of the city. Her project is to create an understanding of the city defined through chaos and criminality attributable to migration. Another SD politician, Lena, also in her late sixties, developed a similar argument:

I wanted to discuss the Islamisation of the city. But nobody listens. It's hard being a local politician, I think, because there are a lot of questions that might not be so ideological; there are a lot of figures.

The threat of 'Islamisation' is also a very common argument among the Sweden Democrats. During her interview, Lena introduced the word 'Islamisation', defining it indirectly when talking about her engagement in the Sweden Democrats:

You know, what will come, that our grandchildren will be all praying to Mecca and our granddaughters will not be allowed to go outside the home. 
Another informant told us that she felt very uncomfortable in the arena of local politics. While Sweden is threatened by 'Islamisation' (informant's words), she felt she had to sit quietly through meeting after meeting, trying and partially failing to find a way to adapt the SD's political demands to the 'dull and limited' (informant's words) everyday life of municipal council politics.

It is also interesting that budget issues ('the figures'), a topic that most members of the other political parties would find relevant, considering that municipal finances and taxation (with about $30 \%$ of income being taxed by municipalities and counties) are the subject of the most important source of political disagreements, are offered by Lena as an example of the nonideological.

Despite their welfare-friendly rhetoric, their members rarely vote with the red-green block (Social Democrats, the Left party and the Swedish Green party), and generally support the neoliberal agenda of the right-wing parties focusing on reducing tax as well as privatisation (Wångmar 2011). However, since our study, the SD have substantially increased their skill in political manoeuvring, in formulating political proposals, in intervening in budget discussions and in trying to play the two blocs against each other. ${ }^{5}$

However, while some of our informants experience restrictions in municipal politics on shaping their political objectives, others find that the SD has created a place for them in the context of local politics, where their knowledge and experience are acknowledged on an

\footnotetext{
${ }^{5}$ The most significant example is how they broke with a tradition of voting only on their own budget only in the national parliament, by voting in support of the right parties' budget proposal. This created a situation in which a social democratic government was forced to implement a right-wing national budget.
} 
individual level. This was especially the case for women claiming expertise as mothers on the School Board or on the Children and Youth Board.

Our empirical material challenges the widespread notion of the SD as 'only' a one-issue party (anti-migrant). Subordinated to a culturally racist core, there is continuously ideological and political expansion of new topics. This increasingly broadened societal vision has led some scholars to conceptualise SD a fascist party (Arnstad, 2013). They have in their parliamentary motions systematically tried to link their proposals to their worldview, emphasising law and order (decreasing security in the city, particularly for women, owing to migrants), challenging multicultural education and feminist-inspired pedagogical frameworks and consistently arguing for more resources to be put into elderly care (paid through reducing/removing what are supposed to be the costs of migration). Nela, summarises the SD's agenda as follows:

And that's also another stage in our policy... There can't be social benefit fiddles when we need money elsewhere in the municipality, money going to social benefits for migrants, or to these cultural things... then for our elderly, whom we're always saving on, cutting back on staff... There is rarely a doctor on hand at a nursing home, but then there's a nurse at best, if she even visits, because there are no nurses during the night. And then you're connected to a doctor and a nurse over the telephone. But, you know, a nurse can't provide a complete diagnosis of an older person. And what we're saying is that then one could use the money to have maybe a doctor coming over.

A central demand of the party at the municipal level is a 'multicultural financial statement' (Sverigedemokraterna, 2012a, p. 16) aimed at identifying resources spent on migrants, 
broadly defined. It focuses especially on costs for refugees, home-language and multicultural education, school and day care for migrants, social assistance, etc. In Nela's narrative, the category of the elderly (assumed to be 'Swedish') is set against the costs of migrants (represented as welfare-dependent). Whereas cuts in welfare services are the effect of a shift towards neoliberal policies in the late eighties, Nela assumes that they are a consequence of migration. The 'our' in our elderly is also worth exploring. It speaks of a definition of belonging in which the (often violent) exclusion of Others is understood through notions of love, of care of 'our own' (Ahmed, 2003). Nela could never see herself as belonging to a racist party, even if she expressed racist views regarding migrants' violent personalities, laziness and utilisation of the welfare state. She sees herself as somebody protecting the interests of those who cannot speak for themselves (Nela's words), whose needs have been marginalised because of the costs of migrants. Paradoxically, many of the employees within the welfare service caring for the elderly have a migrant background.

'Our elderly' is the core of a number of the SD's interventions, such as the 2010 election film in which Burqa-dressed women (many with pushchairs and one wearing a large diamond ring) were seen as taking away pension resources from an elderly white 'Swedish' woman (Sverigedemokraterna and Axelsson, 2010). Here we discern metaphors characterising migrants as a threat to the national body, both in terms of representing migration metaphorically as a rape of the national body (migrant men) and of migrants as a parasite, reproducing and annihilating the national body from within (migrant women).

The election advert ends with the question whether one (as a voter) should curtail the migration or the pension break. It was pitting migrant Muslim women against a light-skinned old women, using a racist image language. In most of the interviews, the category of migrant was juxtaposed with the category of retired, elderly people. Many other categories could serve 
as binary oppositions (at times youth, unemployed, sick), but the focus on migrants vs the elderly captures the lived experiences of female SD politicians and the Swedish Democrats' generation profile; elderly voters are central to the success of the party (Eklund and Järnbert, 2013).

In the interviews with the female activists of the SD, care became an important theme, but it was care mediated through a culturally racist prism. The concept of caring racism (author/s reference b) describes the political articulation of racism with particular forms of (racist) femininity in the Swedish context.

The mainspring for mobilising activists to the party is undeniably a culturally racist ideology. These women share a particular view of a perceived Muslim threat to the Swedish welfare state: arguments about the impossibility of integrating Muslims or the burdens of Muslims (economically but also in terms of criminality) were central reasons for joining the party.

\section{Female SD politicians: gender equality, a marginal issue}

Most of our informants were not especially interested in gender issues, a lack of engagement that sets them apart from most female politicians in Sweden. Their focus was on migration and migrants. Gender entered their narratives by three different paths. The first was through the before/now dichotomy in their description of the changes within the country, where

feminism often functioned as a code word for social problems and undesired changes, as Åsa argues: 
Things were different before. Divorce is okay. I am divorced. But people divorce ... well, like abortion. They do not take things seriously. And those feminists have parties when they divorce.

Åsa's boundaries are worth reflecting because they mirror a more general tension regarding the Sweden Democrats' relation to the field of Swedish gender equality. Åsa is referring to a volume edited by two feminist journalists aiming to shift the focus from the notion of divorce as catastrophe to that of divorce as opportunity. It is her own experience of divorce that is her point of departure for understanding how things were before. Åsa seems to be arguing that both divorce and abortion are acceptable things because people engage in them. What Åsa challenges is what she perceives as the superficiality that pervades experience of these practices today. The feminists seem to represent a new time when divorces are celebrated. The phrase 'that things have gone too far' was often repeated by our informants: 'things' meaning migration, multiculturalism, integration and often also the cultural understanding of gender and sexuality that the SD informants perceived as threatening the nuclear family.

The second path was through the means of a silence/speech approach often used by the party. When asked about gender equality issues, the informants tended to follow the SD's political rhetoric that is based on the equation, 'We, the SD, say what people think and feel [but dare not say]'. The same argument is used about gender equality, as the quote from this informant illustrates: 'Everyone would like to, would want to stay at home with their children if they could.' The argument that people/women dare not challenge the authoritarian gender norms established by the Social Democrats but 'invented' by the feminists (the silence argument) is related to the conviction that the party voices the opinions of those who dare not speak out. 
In the propaganda film that the SD women created during the EU campaign 2014, a young (blonde) woman in a tiny bikini, posing in the genre of men's magazines, was portrayed near the sea. The SD women explained that they consciously chose this image to challenge the extremism of Swedish feminism that, in their worldview, would oppose women's representation as sex objects. According to them, the image of the nearly naked woman clearly showed that women could make other choices (Thomsen and Svanberg, 2014).

The third and most important way by which gender equality enters into the narratives is in relation to migrants and migration, as illustrated in the following two quotes. In the first, gender is linked to equality with what the majority of the informants believe is the key political issue for $\mathrm{SD}$, namely migration:

Yes, partly because we had achieved gender equality here. But now, especially here in this town when you're out, a lot of women feel unsafe when they go out... Not all men are like Swedish men, you know. Then we have the problem with those poor girls, with those terrible traditions... what I just said about being oppressed and that we want gender equality. But okay, everybody wants that, but then you shouldn't exaggerate either, but it... (Lisa)

On March 8, 2012 the SD women's network presented a film that aimed to put the topic of 'honour killing' on the public agenda. The first scene of the film showed a female body brutally beaten; in the second, a blonde young women cleaned the blood, accompanied by a speaker's voice saying, 'Think that culture can kill.' The SD women active in Almedalen before the 2014 Swedish elections systematically linked rape to migration, asserting that the courses offered to refugees seem unable to teach them Swedish cultural values regarding women. 
The Alliance [reference to the right-wing coalition in government] has introduced community education classes for asylum seekers, but apparently without success... Look at the increasing number of honour crimes and the exploding figures regarding rape (Borg, 2010).

The SD women's website makes the same connection but in a quite different way:

Therefore, we believe that at least 50 million $[\mathrm{kr}]$ annually should be moved from gender studies and from the state-funded equality projects that do not have any real impact on actual gender equality in society, such as research that tries to clarify whether a fork is seen as male or female, and instead specifically earmark the sum for the fight against honour-crime problems (Borg \& Herrstedt, 2012).

In the first quote, it is the presence of migrant men that threatens the existing gender equality in Sweden. In the second, it is the presence of migrant women ('those poor girls') that explains the need for gender equality, a gender equality that should not be taken too far. In the second quote, it is also the presence of feminists (gender scholars) supported by the state that must be challenged in order to shift gender policies into conformity with the worldview of the party.

Our informant locates the SD within a neo-conservative tradition regarding gender and sexuality, discussing what is normal: 
I think normal marriage is normal, you know. But they can live together. They can live together, but I don't like [that] two women can get married, two men getting married and after that they want to have children. I don't like it. I'm mostly thinking of the children - it is not good for children. Having two daddies or two mummies there, you know, how are they treated in school? I don't like that, you see... normal relationships as it has been in the past and not complicating everything. Completely normal, then we will have a good society as well. (Maria)

The phrase 'complicating everything' is worth further reflection. It highlights one of the party's central arguments aimed at creating tension between the people (whom they claim to represent) and the elite (whom they claim to challenge). Feminists with their demands for new family forms or more inclusive understandings of the variety of genders and sexualities create problems, make what is simple difficult.

\section{All the same? Resistance and normalisation at the everyday level}

Discussing the need for speed bumps to regulate traffic, a SD representative takes the stage. Looking towards a Green Party representative of migrant background, he asserts: 'It is only migrants that live in the inner city. I do not understand why you people do that?' A representative from the right quickly demands a word, strongly rebutting the SD's arguments (many of the right's voters with children also live in the inner city). Before the representative from the Green Party has a chance to answer, the leading Board member (a senior 
Social Democrat) says in a low voice: 'Here in Sweden, we treat our fellow politicians with collegiality and respect. Everybody has to conform to this Swedish political culture.' And, turning to the SD member, 'You should apologise.' [Applause from the other members of the Board] (from fieldwork notes at a council meeting)

Knowing that it is mainly young leftist antiracists who participate in demonstrations against the SD (Wasshede, 2010), this senior Social Democrat does not represent the categories present in street protests, but he uses both his power and that of the nation to challenge the SD through their rhetoric. The SD representative is portrayed as outside the frame of 'Swedishness' and made to apologise for being 'un-Swedish'.

While in SD's official rhetoric the extra-parliamentary left is often emphasised as a threat that they face constantly, our informants highlight other forms of dis-identification from their worldview, forms of dis-identification aiming to challenge the notion that the Sweden Democrats are (as they often argue) a normal party of normal people. Ursula, who told us the first story, is in her late fifties and active on the elderly board. Kim, who told us the second story, is nearly seventy and has been politically active in other parties since her youth.

For example, it could be like when we had a Christmas dinner. Then one of the Social Democrats had her glass next to mine - no, she had put her glass like that [informant shows how the glasses stood next to each other]. So I thought, 'But I'll fill it up; I don't need to sit far away.' So when it was my turn I sat next to her like this. But when she saw that I was going to sit next to her, she took her glass and moved somewhere else. 
And then two girls came in, who were maybe 13-14 years old, and they came with their mother - or it was probably one of the girls' mother - and they said, No, Mum, let's actually ask the Sweden Democrats what they stand for.' And so she just, 'No, you're certainly not going to do that. Get over here.' 'No, Mum, no, I want to know what they stand for.' And they came up to us, and they asked normally and properly, and they got a journal each and thank you for this and that, quite normally, but the mother didn't like it. And I heard the mother saying to the girls, 'They are racist.' And that is not true.

Both stories are about drawing boundaries. Both stories are about conflicts between women. In the first scene, the Christmas dinner is the arena, a ritual that aims to create social cohesion despite political differences, where we (local politicians) talk about other things than politics (children, grandchildren, summer cottages).

In the story, the informant draws attention to her own impeccable social openness and portrays the other female politician as rude. It is a strong marker in the context of a party. The second story also positions the informant as professional (completely normal) and the mother as authoritarian and prejudiced. From the informant's account it is hard to know what the mother actually thought and how she acted, but there is certainly a suggestion that she conveyed to the children that, although the SD looked like any other party, it was not. The children will remember the mother's distress. It is such forms of resistance that seem difficult to handle and that are perceived as most offensive. 
But where does their belief that everyone thinks like them in spite of the opposition come from? These beliefs evolve partially from the informants' experiences in municipal politics that account for private recognition despite strong public opposition. But the private support and public dissociation that many point to also create mixed feelings of both pride and impotence:

Well, behind the backs of their own, they pat you on the shoulder and tell you: 'It's a good thing you guys exist and say what we all know.' And it has actually happened to me, literally. (Bianka)

It is the physical proximity of pats on the back that is used to describe a closeness that is denied in public. There are so far few examples of organised collaboration between established parties and the Sweden Democrats, although more discussion takes place regarding the extent to which the SD's proposals and rhetoric have been adopted (Westberg, 2013). The hope of recreating the experience of the Danish People's Party, which succeeded in becoming a vital voice in Danish politics (Berggren and Neergaard, 2015), a similar development for the Progress Party in Norway (Akkerman and Hagelund, 2007), neither with the stigma of a neo-Nazi history, has not (yet) been fulfilled. Swedish political parties have denied the Sweden Democrats the right to be a 'normal' party, while the Sweden Democrats attempt to maintain an underdog position but also to become 'normal'. Below is one of the normalising narratives that are a common theme in our interviews, told by Kim, whom we introduced earlier:

And in the beginning then, well, just after the election then, then it was very, the atmosphere was very cold. They would say, for example, at board meetings... And then the Social Democrats were on one side and then the Alliance on one 
side and we stood in the middle, drinking our coffee. We've only got two people on each board: a substitute and a regular. So we sat at our table and stood in our little corner and had coffee. But, after a couple of times it started, there was someone from one group and so the next time there was someone from the other group. So now it's nothing. Now we're invited, 'Come and sit here with us,' or 'Sit with us,' or... And it's quite nice.

At the beginning of the quote, the informant notes the initial coffee break as the arena where social relations created a sense of belonging from which she was excluded, a marginalisation that decreased as time passed by, ending with the two parties competing to invite her to sit with them during such breaks.

Most of them explained the shift by saying that, after a while, the other political parties understood that they were ordinary people and that there was nothing strange about the party. European racism has been central to the construction of European nation states and to a legitimisation of European colonialism (Ware, 1992). Consequently, we fully agree with many of our informants when they argue that there is nothing strange about the SD. Although the exclusionary racism of SD is a particular form of racism, racism is present beyond the Sweden Democrats, in different forms an integral part both of European colonial history and of the politics of the European Union and European states of today.

\section{Conclusions}


In this article, the focus has been on understanding women representatives in municipality politics of what we conceptualise as a cultural racist party - the Sweden Democrats. Local, especially municipal but also county, politics is important in the Swedish constitutional arraignment of state power with important taxation discretion, but very limited influence on migration politics. While patriarchal structures are still of importance in local politics, most established parties have succeeded in narrowing and even closing gender gaps in representation, and in that context the striking underrepresentation of women in the SD stands in marked contrast.

Despite the rhetoric of containment, Swedish political parties (particularly the right-wing parties, but to some extent also the Social Democrats) have partially legitimated some of the arguments on migration, migrants and especially Muslims that the SD proposes. This reinforces the narratives of the women SD activists who in our interviews spoke about finding support among some of the mainstream parties. Unlike mainstream research on extreme rightwing parties, which on the one hand downplay or even obscure the racism of these parties and on the other hand rarely employ a gendered analysis, we see (cultural) racism and antifeminism as central for their agenda.

Today the Nordic scene is composed of two governments where right wing coalitions include cultural racist parties (the True Finns in Finland and the Progress party in Norway). Furthermore, in Denmark the Danish Peoples party came through as the largest party in the European Parliament election, and as one of the largest parties in the run-up of the Danish Parliamentary election 2015. While the 2014 elections gave the Sweden Democrats a record $13 \%$, it is still one of the smaller and more isolated of Nordic cultural racist parties, although opinion polls indicate a continuing increase in support, especially among men. This 'Nordic' 
phenomena challenge causal explanations that link in deterministic ways the process of marginalisation and rising unemployment in the context of neoliberalism with support for these parties. They also challenge explanations that identify straightforward connection between numbers of migrants and the success of these parties. Thus, we argue, the electoral success of the Sweden Democrats should not be presumed to be only an effect of neoliberal policies or migration regimes.

We would argue that the often denied colonial complicity of the Scandinavian region (Keskinen et al., 2013), the strong but concealed support for Nazism among its elites and a migration regime regulated through forms of subordinated exclusion are relevant elements in understanding the parliamentary articulation of racism within the 'Nordic model'. The female activists and representatives of the SD seem to be part of a small group of women who have successfully been interpellated by the SD and similar antifeminist ideology. To be a female representative of the Sweden Democrats is to be part of a minority of women in a Swedish political landscape in which a central split concerning support for a cultural racist party is shaped by gender.

\section{References}

Ahmed, S. (2003). In the Name of Love. Bordelands. Vol. 2 (3).

Akkerman, T., and Hagelund, A. (2007). 'Women and children first!' Anti-immigration parties and gender in Norway and the Netherlands. Patterns of Prejudice, 41(2), 197-214. 
Andersson, R., and Molina, I. (2003). Racialization and migration in urban segregation processes: Key issues for critical geographers. In J. Öhman \& K. Simonsen (Eds.), Voices from the North: New Trends in Nordic Human Geography (261-282). Aldershot: Ashgate.

Arnstad, H. (2013). Älskade fascism: de svartbruna rörelsernas ideologi och historia.

Stockholm: Norstedt.

(Author/s reference a).

Bacchetta, P. and Power, M. (2002). Right-Wing Women: From Conservatives to Extremists around the World. New York: Routledge.

Back, L. (2007). The Art of Listening. Oxford: Berg Publishers.

Balibar, E. (1991). 'Is there a 'Neo-Racism”?', in Balibar, E. and Wallerstein, I. (eds) Race, Nation, Class: Ambiguous Identities. London: Verso.

Barker, M. (1981). The New Racism: conservatives and the ideology of the tribe. London: Junction books.

Berggren, E. and Neergaard, A. (2015) 'Populism - Protest, democratic challenge and rightwing extremism', in Dahlstedt, M. and Neergaard, A. (eds) International Migration and Ethnic Relations: Critical Perspectives. London: Routledge.

Betz, H.-G. (2005). Against the system: radical right-wing populism's challenge to liberal democracy, in Rydgren, J. (ed.), Movements of Exclusion: Radical Right-wing Populism in the Western World (25-40). Hauppauge, NY: Nova Science.

Billig, M. (1995). Banal Nationalism. London: Sage Publications.

Blaut, J. (1992). 'The theory of cultural racism', Antipode, 24(4), 289-299.

Boreus, K. (1997). The shift to the right: neo-liberalism in argumentation and language in the Swedish public debate since 1969. European Journal of Political Research, 31(3), 257286. 
Bulbeck, C. (1997). Reorienting Western Feminisms: Women's Diversity in a Postcolonial World. Cambridge: Cambridge University Press.

Castles, S., and Miller, M. J. (2003). The Age of Migration. Basingstoke: Palgrave.

Deland, M., \& Westin, C. (2007). Brunt. Nationalistisk och nazistisk mobilisering $i$ vår närmaste omvärld under efterkrigstiden. Stockholm: Atlas.

DeVault, M. (1996). Talking back to sociology: distinctive contributions of feminist methodologies. Annual Review of Sociology, (22), 29-50.

Ekström von Essen, U. (2006). Sverigedemokraterna i de svenska kommunerna 2002-2006. En studie av politisk aktivitet, strategi och mobilisering. Norrköping: Integrationsverket. Esping-Andersen, G. (1990). The Three Worlds of Welfare Capitalism. Cambridge: Polity. Esseveld, J., and Eyerman, R. (1992). Which side are you on? Reflections on methodological issues in the study of 'distasteful' social movements, in Diani, M. and Eyerman, R. (eds.), Studying Collective Action. London: Sage.

Fennema, M. (1997). Some conceptual issues and problems in the comparison of antiimmigrant parties in Western Europe. Party Politics, 3(4), 473-492.

Fjæstad, B., \& Björkman, J. (Eds.). (2012). Tungan på vågen: vågmästare och balanspartier. Göteborg: Makadam.

Gullestad, M. (2002). Invisible fences: egalitarianism, nationalism and racism. The Journal of the Royal Anthropological Institute, 8(1), 45-63.

Collins, H. P. (1998). 'It's All in the Family: Intersections of Gender, Race and Nation', Hypatia, 13(3), 62-82.

Hübinette, T. and Lundström C. (2014). Three phases of hegemonic whiteness: understanding racial temporalities in Sweden. Social Identites, 20(6), 423-437.

Kaplan, J. and Weinberg, L. (1999). The Emergence of a Euro-American Radical Right. New Brunswick: Rutgers University Press. 
Keskinen, S., Tuori, S., Irni, S., and Mulinari, D. (2007). Complying with Colonialism:

Gender, Race and Ethnicity in the Nordic Region. London: Ashgate.

Keskinen, S. (2013). Antifeminism and white identity politics: political antagonisms in radical right-wing populist and anti-immigration rhetoric in Finland. Nordic Journal of Migration Research, 3(4), 225-232.

Koonz, C. (1987). Mothers in the Fatherland: Women, the Family, and Nazi Politics (1st edn.). New York: St. Martin's Press.

Lister, R. (2009). A Nordic nirvana? Gender, citizenship, and social justice in the Nordic welfare states. Social Politics, 16(2), 242-278.

Mella, O. and Palm, I. (2013). Mångfaldsbarometern 2013. Uppsala University, Department of Sociology.

Mudde, C. (2000). The Ideology of the Extreme Right. Manchester \& New York: Manchester University Press.

Mudde, C. (2007). Populist Radical Right Parties in Europe. Cambridge: Cambridge University Press.

Mukhtar-Landgren, D. (2008). Entreprenörsstaden, in Tesfahuney, M. and Dahlstedt M. (eds.) Den bästa av världar? Betraktelser över en postpolitisk samtid. Hägersten: Tankekraft förlag.

Norocel, O. C. (2013). 'Give us back Sweden!' A feminist reading of the (re)interpretations of the Folkhem conceptual metaphor in Swedish radical right populist discourse. NORA: Nordic Journal of Feminist and Gender Studies, 21(1), 4-20.

Nyberg, A., \& Jonsson, I. (2009). Sweden: precarious work and precarious unemployment, in L. F. Vosko, M. MacDonald, and Campbell I. (eds.), Gender and the Contours of Precarious Employment. London: Routledge. 
OECD. (2013). Crisis squeezes income and puts pressure on inequality and poverty: New results from the OECD Income Distribution Database.

Passmore, K. (Ed.). (2003).Women, Gender and Fascism in Europe, 1919-45. New Brunswick, NJ: Rutgers University Press.

Pred, A. (2000). Even in Sweden: Racisms, Racialized Spaces, and the Popular Geographical Imagination. Berkeley, CA: University of California Press.

Puar, J. (2007). Terrorist Assemblages: Homonationalism in Queer Times. Duke University Press.

Rydgren, J. (2005a). Is extreme right-wing populism contagious? Explaining the emergence of a new party family. European Journal of Political Research, 44, 413-437.

Rydgren, J. (2005b) Movements of exclusion: radical right-wing populism in the Western world. New York: Nova Science.

Sager, M. (2011). Everyday Clandestinity: Experiences on the Margins of Citizenship and Migration Policies. Lund: Faculty of Social Sciences, Centre for Gender Studies, Lund University.

Sainsbury, D. (2004). Women's political representation in Sweden: discursive politics and institutional presence. Scandinavian Political Studies, 27(1), 65-87.

SCB (2015) Statistics Sweden, www.scb.se

Schierup, C.-U. and Ålund, A. (2011). The end of Swedish exceptionalism? Citizenship, neoliberalism and the politics of exclusion. Race \& Class, 53(1), 45-64.

Schierup, C.-U., Hansen, P. and Castles, S. (2006). Migration, Citizenship, and the European Welfare State: a European Dilemma. Oxford: Oxford University Press.

Selberg, R. (2013). Nursing in times of neoliberal change: an ethnographic study of nurses' experiences of work intensification. Nordic Journal of Working Life Studies, 3(2).10-35. 
Siim, B. (1994). Engendering democracy: social citizenship and political participation for women in Scandinavia. Social Politics: International Studies in Gender, State \& Society, 1(3), 286-305.

Towns, A., Karlsson, E. and Eyre, J. (2014). The equality conundrum: gender and nation in the ideology of the Sweden Democrats. Party Politics, 20(2), 237-247.

Vasileva, K. (2011). Population and Social Conditions. Eurostats, Luxembourg: European Commission.

Wängenerud, L. (2012). Viner partipiska hårdare i partier med vågmästarroll. In J. Björkman and B. Fjæstad (eds.), Tungan på vågen: vågmästare och balanspartier. Gothenburg. Makadam.

Wångmar, E. (2011) 'Ingen kopia av riksdagsvalet. Utfallet av valen till kommunfullmäktige 2010 i landets 290 kommuner, med särskilda fallstudier av Sverigedemokraternas agerande', Statsvetenskaplig tidskrift, 113(4), 425-439.

Ware, V. (1992). Beyond the Pale: White Women, Racism and History. London: Verso.

Wasshede, C. (2010). Passionerad politik: om motstånd mot heteronormativ könsmakt. Malmö: Bokbox.

Yuval-Davis, N. (2012). The politics of belonging: intersectional contestations. Los Angeles, Calif.: Sage.

\section{Empirical Material}

Arvidsson, M. (2010) ‘Grov rasism på SD-politikers blogg’, Helsingborgs Dagblad, September. Available at: http://www.hd.se/lokalt/landskrona/2010/09/03/grov-rasism-pasd-politikers-blogg/ (Accessed: 4 June 2015). 
Baas, D., \& Holmén, C. (2013, December 10). Flera politiker skriver anonymt på hatsajter. Expressen. http://www.expressen.se/nyheter/expressen-avslojar/flera-politiker-skriveranonymt-pa-hatsajter/ (accessed 140822)

Borg, T. (2010) 'Problem måste belysas för att kunna lösas', Therese Borgs blogg, 30 August. Available at: https://thereseborg.wordpress.com/2010/08/30/problem-maste-belysas-foratt-kunna-losas-2/ (Accessed: 4 June 2015).

Borg, T., \& Herrstedt, C. (2012, October 4). Regeringens passivitet är ett svek mot utsatta kvinnor. Newsmill. Retrieved from http://www.newsmill.se/artikel/2012/05/03/regeringens-passivitet-r-ett-svek-mot-utsattakvinnor (accessed 130422)

Eklund, J. and Järnbert, M. (2013) ‘SD-politikerna mest lika sina väljare', Välfärd, Statistiska Centralbyrån, 5-7.

Malmö Stad, (no date) Jämställdhet och mångfald, Malmö Stad. Available at: http://malmo.se/Foretagande--jobb/Malmo-stad-som-arbetsgivare/Vartforhallningssatt/Jamstalldhet-och-mangfald.html (Accessed: 4 June 2015).

Skeri, N. (2010) 'Lokal SD-kandidat försvarar hatbrott', UNT.se, 8 September. Available at: http://www.unt.se/uppland/uppsala/lokal-sd-kandidat-forsvarar-hatbrott-1035991.aspx (Accessed: 4 June 2015).

Sverigedemokraterna. (2012a). Generella riktlinjer för kommunpolitik [General Guidelines for Municipal Policy]. Retrieved from https://sverigedemokraterna.se/files/2013/04/riktlinjer_sd_kommunalpolitik_04_02.pdf (cited 130716).

Sverigedemokraterna (2012b). Kommunikationsplan 2014 [Communication Plan, 2014]. Retrieved from 
https://sverigedemokraterna.se/files/2012/12/Kommunikationsplan_2014.pdf (cited 130109).

Sverigedemokraterna \& Axelsson, M. (2010). Sverigedemokraternas officiella reklamfilm, tv4 [Sweden Democrats' Official Commercial, tv4]. Retrieved from http://www.youtube.com/watch?v=5UiUdpYVubY (cited 130628).

Thomsen, D. and Svanberg, A. (2014) 'SD-kvinnor om sin lättklädda reklamfilm: “Tycker att den är ganska tydlig”', Dagens Media, 22 May. http://www.dagensmedia.se/nyheter/kampanjer/article3828524.ece (cited 140422).

Westberg, A. (2013) '”Hur trovärdig är den hårda linjen?”', Sydsvenskan, 3 August. Available at: http://www.sydsvenskan.se/opinion/aktuella-fragor/hur-trovardig-ar-denharda-linjen/ (Accessed: 4 June 2015). 